\title{
SNAKEBITES IN SOUTHWESTERN GOIÁS STATE, BRAZIL
}

\author{
PACHECO U. P. (1), ZORTÉA M. (1)
}

(1) Federal University of Goiás, Jataí, Goiás State, Brazil.

ABSTRACT: The present study evaluated snakebite cases recorded by the Southwest II Regional Health Bureau [Regional de Saúde Sudoeste II], Goiás State, Brazil. The following data were analyzed: accident period; patient's age and gender; bite site; envenomation severity; and time elapsed between the bite and medical treatment. We evaluated 211 cases recorded between January 2002 and December 2005 , which resulted in an incidence coefficient of 32.4/100,000 inhabitants. Most accidents were due to the bite of snakes from the Bothrops genus (78.2\%). The months between January and April had a larger number of accidents (93\%-44.1\%), although no significant differences were observed. Only one death occurred, resulting in a mortality rate of $0.5 \%$. The lower limbs were the most frequently affected $(66.3 \%)$. The majority of the victims were male $(75.1 \%)$. The age group of most of the patients was from 21 to 30 years $(20.8 \%)$. The accidents were classified as mild, moderate and severe, representing $44.9 \%, 47.6 \%$ and $7.5 \%$ of the cases, respectively. The time elapsed between the accident and medical treatment was less than $3 \mathrm{~h}$ in most of the cases $(80.7 \%)$, reflecting the high frequency of mild and moderate accidents (92.5\%) as well as the large number of healed patients.

KEY WORDS: snake bites, Cerrado, Jataí, Goiás.

CONFLICTS OF INTEREST: There is no conflict.

\section{CORRESPONDENCE TO:}

ULISSES PERES PACHECO, Universidade Federal de Goiás, Campus Jataí, Coordenação de Ciências Biológicas, $\operatorname{Br} 364$, km 192, 75801-615, Jataí, Goiás, Brasil. Phone: 643632 1510. Email: ulissesperes@hotmail.com. 


\section{INTRODUCTION}

Nowadays, there are about 2,900 snake species identified worldwide; they are distributed into 165 genera and 30 families (8). In Brazil, two families of venomous snakes can be found: Viperidae, represented by five genera (Bothriopsis, Bothrocophias, Bothrops, Crotalus and Lachesis) totalizing 30 species, and Elapidae, represented by the coral snakes, which belong to the genus Micrurus, comprising 22 species (14).

Accidents caused by venomous snakes represent a significant public health problem, especially in tropical countries (20). According to the National Health Foundation FUNASA, Brazil, about 81,611 snakebite accidents occurred in Brazil from January 1990 to December 1993, yielding a coefficient of 13.5 accidents/100,000 inhabitants. Among the different regions of the country, the highest index was observed in the central-western region, with 33.3 accidents $/ 100,000$ inhabitants, followed by the northern region, with 23.3 accidents/100,000 inhabitants (4). These accidents are common in rural zones, mainly in canopy-gap areas. The Goiás State Health Bureau recorded 3,261 accidents caused by venomous snakes from January 1998 to December 2000, with an incidence coefficient of 21.7/100,000 inhabitants (19).

Bites by snakes from the Bothrops genus (jararacas, lanceheads) account for about $75 \%$ of the snakebite accidents in Brazil $(4,19)$. Silva et al. (27) evaluated 90 cases of snakebite accidents with venomous snakes in a central region of the country and concluded that $74 \%$ were caused by Bothrops, $24 \%$ by Crotalus (rattlesnakes) and $2 \%$ by Micrurus species (27).

Snakebite accidents are often associated with venomous snakes, although Albolea et al. (1) verified that nonvenomous snakes are responsible for about $40 \%$ of the accidents in the state of São Paulo, Brazil (1). According to Ribeiro et al. (24), bites by the nonvenomous snake Philodryas olfersii can cause symptoms similar to those caused by the bite of Bothrops snakes (24).

The present study aimed at evaluating the epidemiological aspects of the snakebite accidents recorded by the Southwest II Regional Health Bureau-Jataí, Goiás State, Brazil, as well as at supporting future actions for the prophylaxis and epidemiology of these accidents. 


\section{MATERIALS AND METHODS}

Epidemiological data were collected from the Southwest II Regional Health BureauJataí, Southwestern Goiás State, Brazil. We analyzed 211 investigation files of snakebite victims between January 2002 and December 2005.

The Southwest II Regional Health Bureau-Jataí comprises 10 districts of the southwestern area of Goiás: Aporé, Caiapônia, Chapadão do Céu, Doverlândia, Jataí, Mineiros, Perolândia, Portelândia, Santa Rita do Araguaia, and Serranópolis (10); together they have 162,932 inhabitants and a total area of $41654.98 \mathrm{Km}^{2}$, corresponding to $12.24 \%$ of the total area of Goiás State (11).

Information about the day and month of the accident, the patient's age and gender, the bitten anatomical site, and the time elapsed between the accident and the first medical procedures was collected in all analyzed cases.

The envenomation severity and the evolution of cases were recorded. Data about complications of envenomation cases were not analyzed, whereas they are well described in literature. The Chi-square test was used to analyze whether there was a monthly prevalence of accidents.

\section{RESULTS}

Analysis of 211 files during these four years indicated that $78.2 \%$ of the accidents were caused by Bothrops snakes, $12.3 \%$ by Crotalus snakes, 0.9 by nonvenomous snakes, and in $8.5 \%$ of the cases, the animal responsible for the accident could not be identified (Table 1). Eighteen files were excluded from the analyses due to the lack of information about the animal responsible for the accident.

There was an average of 52.75 annual cases, and the average of cases per month was 17.58 with a variation coefficient of $32 \%$. January, February, March, and April showed larger numbers of accidents, totalizing 93 (44.1\%) out of the analyzed months (Figure 1). However, these higher incidences did not reflect significant statistical differences $\left(x^{2}=14.27 ; \mathrm{df}=11 ; p=0.218\right)$.

Information about the injured anatomical site was available in 190 files. The most affected limbs were the feet $(40.5 \%)$, followed by the hands $(27.9 \%)$ and the legs (25.3\%). Thighs, trunk, arms and forearms accounted for $6.3 \%$ of the cases (Table 2).

The majority of the victims $(\mathrm{N}=193)$ were male $(75.1 \%)$ and belonged to the age group ( $N=192)$ from 21 to 30 years $(20.8 \%)$ and from 31 to 40 years $(17.2 \%)$. 
Individuals between 51 and 60 years as well as those older than 60 were the least attacked group (Table 2). With regard to the accident place $(\mathrm{N}=189)$, the majority of the cases occurred in the rural zone (Table 2).

Out of the 187 files containing available data on the accidents severity, $44.9 \%$ represented mild cases, $47.6 \%$ moderate cases, and $7.5 \%$ severe cases (Table 3 ).

Most patients received medical treatment within $0-1 \mathrm{~h}$ and $1-3 \mathrm{~h}$ after the accident, representing $73(39 \%)$ and $78(41.7 \%)$, respectively, out of $151(80.7 \%)$ cases (Table $3)$.

In general, the patients' clinical state progressed to healing (89.8\%). Healing with health consequences was observed in five cases $(2.7 \%)$ and there was only one record of death $(0.5 \%)$ out of all the analyzed files (Table 3 ).

Table 1. Annual distribution of snakebite accidents in the southwest of Goiás State, Brazil, between January 2002 and December 2005.

\begin{tabular}{|c|c|c|c|c|c|c|}
\hline \multirow[t]{2}{*}{ Snake Species } & \multicolumn{4}{|c|}{ Years } & \multirow[t]{2}{*}{ Total (N) } & \multirow[t]{2}{*}{ Total (\%) } \\
\hline & 2002 & 2003 & 2004 & 2005 & & \\
\hline Bothrops & 23 & 46 & 45 & 51 & 165 & 78.2 \\
\hline Crotalus & 2 & 11 & 6 & 7 & 26 & 12.3 \\
\hline Nonvenomous & 1 & 0 & 1 & 0 & 2 & 0.9 \\
\hline Not-identified & 5 & 4 & 4 & 5 & 18 & 8.5 \\
\hline Total & 31 & 61 & 56 & 63 & 211 & 100 \\
\hline
\end{tabular}


Table 2. Frequency of snakebites recorded by the Southwest II Regional Health Bureau, Goiás State, Brazil, between January 2002 and December 2005, according to the patient's age and gender, the bite site, and the accident place.

\begin{tabular}{lccccc}
\hline & Bothrops & Crotalus & Nonvenomous & Total & $\%$ \\
\hline Bite site & & & & & \\
Feet & 64 & 13 & 0 & 77 & 40.5 \\
Legs & 41 & 6 & 1 & 48 & 25.3 \\
Thighs & 1 & 0 & 0 & 1 & 0.5 \\
Hands & 47 & 5 & 1 & 53 & 27.9 \\
Forearms & 2 & 1 & 0 & 3 & 1.6 \\
Arms & 4 & 0 & 0 & 4 & 2.1 \\
Trunk & 3 & 1 & 0 & 4 & 2.1 \\
Accident place & & & & & \\
Rural zone & 146 & 23 & 2 & 171 & 90.5 \\
Urban zone & 17 & 1 & 0 & 18 & 9.5 \\
Age range & & & & & \\
00-10 & 20 & 6 & 0 & 26 & 13.5 \\
11-20 & 24 & 3 & 0 & 27 & 14 \\
$21-30$ & 30 & 8 & 2 & 40 & 20.8 \\
$31-40$ & 30 & 3 & 0 & 33 & 17.2 \\
$41-50$ & 29 & 2 & 0 & 31 & 16.2 \\
$51-60$ & 19 & 1 & 0 & 20 & 10.5 \\
$>61$ & 12 & 3 & 0 & 15 & 7.8 \\
Gender & & & & & \\
Male & 123 & 21 & 1 & 145 & 75.1 \\
Female & 42 & 5 & 1 & 48 & 24.9 \\
\hline
\end{tabular}


U. P. Pacheco and M. Zortéa SNAKEBITES IN SOUTHWESTERN GOIÁS STATE, BRAZIL. J. Venom. Anim. Toxins incl. Trop. Dis., 2008, 14, 1, p. 146

Table 3. Classification and evolution of the cases, and time elapsed between the bite and medical treatment for snakebite accidents in Southwestern Goiás State, Brazil, between January 2002 and December 2005.

\begin{tabular}{lllll}
\hline Cases classification & Mild & $\begin{array}{l}\text { Moderate } \\
\mathrm{N}=84(44.9 \%)\end{array}$ & $\begin{array}{l}\text { Severe } \\
\mathrm{N}=89(47.6 \%)\end{array}$ & $\begin{array}{l}\text { Total } \\
\mathrm{N}=14(7.5 \%)\end{array}$ \\
$\begin{array}{llll}\mathrm{N}=187 \\
\text { Time between the } \\
\text { accident and treatment }\end{array}$ & & & \\
Unknown & $1(0.5 \%)$ & $5(2.7 \%)$ & 0 & $6(3.2 \%)$ \\
$0-1 \mathrm{~h}$ & $37(19.8 \%)$ & $30(16.0 \%)$ & $6(3.2 \%)$ & $73(39 \%)$ \\
$1-3 \mathrm{~h}$ & $36(19.3 \%)$ & $38(20.3 \%)$ & $4(2.2 \%)$ & $78(41.7 \%)$ \\
$3-6 \mathrm{~h}$ & $7(3.7 \%)$ & $8(4.3 \%)$ & $2(1.1 \%)$ & $17(9.1 \%)$ \\
$6-12 \mathrm{~h}$ & $1(0.5 \%)$ & $7(3.7 \%)$ & $1(0.5 \%)$ & $9(4.8 \%)$ \\
$\geq 12$ & $2(1.1 \%)$ & $1(0.7 \%)$ & $1(0.5 \%)$ & $4(2.2 \%)$ \\
Cases evolution & & & & $13(7 \%)$ \\
Unknown & $4(2.2 \%)$ & $8(4.3 \%)$ & $1(0.5 \%)$ & $168(89.8 \%)$ \\
Cure & $79(42.2 \%)$ & $77(41.2 \%)$ & $12(6.4 \%)$ & $5(2.7 \%)$ \\
Cure with consequences & $1(0.5 \%)$ & $3(1.6 \%)$ & $1(0.5 \%)$ & $1(0.5 \%)$ \\
Death & 0 & $1(0.5 \%)$ & 0 & \\
\hline
\end{tabular}

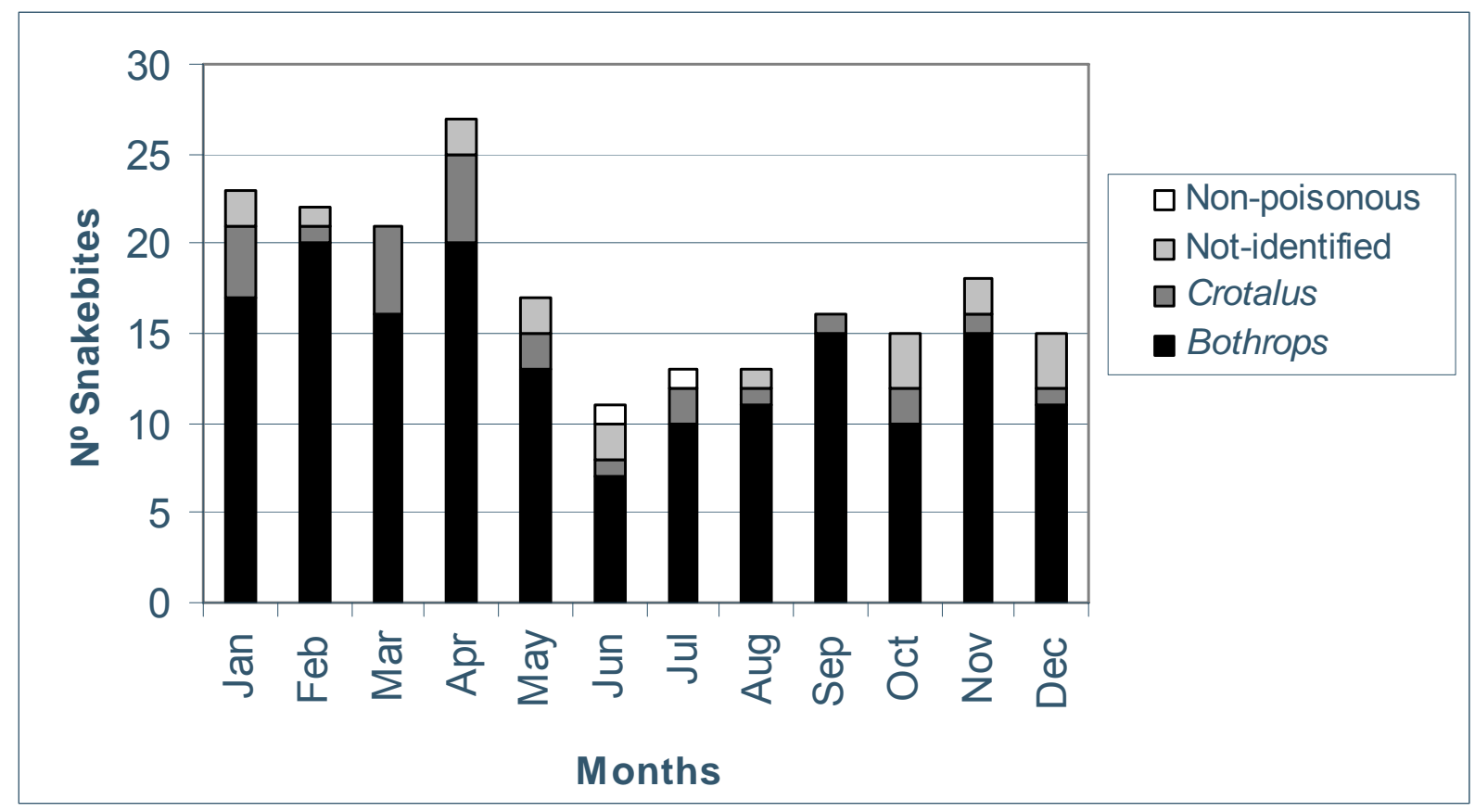

Figure 1. Monthly distribution of snakebites in the Southwest II Regional Health Bureau, Goiás State, Brazil, between January 2002 and December 2005. 


\section{DISCUSSION}

The snakebite accidents recorded in the southwest of Goiás State, Brazil, between January 2002 and December 2005 yielded an incidence coefficient of 32.4/100,000 inhabitants, which was higher than that obtained by Pinho et al. (19) for the whole state of Goiás and over twofold higher than the coefficient found by FUNASA for the entire country (4).

These results can be related to the expansion of agriculture in Goiás State, which caused a series of changes to the environment and the population movement in the countryside, increasing thus the exposition of people to varied accidents, including those caused by venomous animals (3). The significant increase in the number of accidents with Crotalus snakes, which almost doubled in the last four years, can be explained by the higher adaptability of these animals to dry environments (12). Such snakes may have been favored by the substitution of the native vegetation for fields and pasture, increasing the possibility of accidents with humans. However, an opposite process may have been occurring with Bothrops snakes, as the agricultural expansion reduces humid environments and may increase the incidence of these species in places like riparian forests, which are frequently visited by fishers and used for leisure activities, increasing the chances of accidents involving jararacas.

Among the accidents with identified snakes, most of them were caused by venomous snakes from the genus Bothrops, followed by Crotalus. This pattern is similar to the results obtained by Silva et al. in a study in the central area of Brazil (27), as well as to the data from the Goiás State Health Bureau (19). Accidents involving Micrurus snakes, represented by coral snakes, were not recorded. This can be easily explained by the small number of accidents involving this snake genus $(5,7)$.

There were few accidents with nonvenomous snakes; however, it must be emphasized that the involved snake was not identified in $8.5 \%$ of the cases.

According to Franco et al. (9), in Pouso Alegre region, south of Minas Gerais State, Brazil, accidents with Crotalus snakes are almost twofold more common than those caused by Bothrops snakes. These data from the Pouso Alegre Regional Health Bureau are quite distinct from the general pattern verified in Brazil (4), although there are no reports of a high abundance of rattlesnakes in that region.

Pacheco et al. (17) studied the snake species in the district of Jataí, southwest of Goiás State, and observed a predominance of Crotalus, relative to Bothrops snakes. In spite of the higher incidence of rattlesnakes in that region, the frequency of crotalic 
accidents was rather lower than that of bothropic ones, which does not agree with the pattern observed by Franco et al. in Minas Gerais (9).

Snakebite accidents are commoner between October and March, reflecting the season influence such as increase in temperature, rainfall and human activity in rural areas $(4,18,19,22,28)$. A larger number of accidents during the hottest months of the year may be related to the mating season of Viperidae $(2,16)$. Our results showed that the hottest and rainiest months had a higher incidence of accidents, but these differences were not significant.

Considering the accident place and the victim's gender and age, the obtained data were similar to those reported in literature $(5,9,13,15,26)$.

Lower limbs were most frequently affected (66.3\%) and these accidents could have been easily avoided by using boots and spats while laboring in the fields.

For most of the cases (80.7\%), the time elapsed between the accident and medical treatment was less than $3 \mathrm{~h}$, reflecting the larger number of mild and moderate cases as well as healed patients. Snakebite victims treated only after $6 \mathrm{~h}$ have more chances of developing severe envenomation (6).

Snakes from the Bothrops genus have been the main responsible for accidents and deaths, but the percentage of Crotalus accidents which progressed to death is higher $(21,23)$. Out of 211 accident files, the unique case of death was due to the bite by a Bothrops snake, yielding a lethality coefficient of $0.47 \%$, which corroborates the numbers found in literature $(4,19)$.

Our data indicate a high incidence of accidents caused by venomous snakes in the southwestern region of Goiás State, Brazil. Therefore, prevention measures must be more intensified and new studies should be carried out to fulfill the lack of epidemiological work, mainly for the central-western region of Brazil, where the coefficient of accidents is the highest of the country (5).

Martinez et al. (13), in their studies in Vale do Ribeira, São Paulo State, Brazil, found a snakebite incidence rate tenfold higher than that obtained for the whole state of São Paulo. It reinforces the need for further studies in micro-regions of the country. According to Salomão et al. (25), the characteristics of each locality keep close connection with each other, reinforcing thus the need for epidemiological studies in more restricted areas. 


\section{ACKNOWLEDGEMENTS}

We wish to thank Dr. Claudinei Benetti (Principal of the Southwest II Regional Health Bureau-Jataí,) for granting the notification files of snakebite accidents used in this study. Jataí Municipal Superintendence for Science and Technology [Superintendência Municipal de Ciência e Tecnologia de Jataí] provided a grant to U.P. Pacheco.

\section{REFERENCES}

1 ALBOLEA ABP., SALOMÃO MG., ALMEIDA-SANTOS SM., JORDÃO RS. Epidemiologia de acidentes causados por serpentes não peçonhentas no Estado de São Paulo, Brasil. Ci. Biol. Saúde, 1999, 5, 99-108.

2 ALMEIDA-SANTOS SM., ORSI AM. Ciclo Reprodutivo de Crotalus durissus e Bothrops jararaca (Serpentes, Viperidae): morfologia e função do oviduto. Rev. Bras. Reprod. Anim., 2002, 26, 109-12.

3 BENETI AB. Acidentes crotálicos no Estado de Goiás: revisão bibliográfica e avaliação da soroterapia. Goiânia: Universidade Federal de Goiás, Faculdade de Farmácia, 2001. 32p. [Monografia - Especialização].

4 BRASIL. Ministério da Saúde. Fundação Nacional de Saúde. Manual de diagnóstico e tratamento de acidentes por animais peçonhentos. Brasília: Fundação Nacional de Saúde, 1998, 131p.

5 BRASIL. Ministério da Saúde. Fundação Nacional de Saúde. Manual de diagnóstico e tratamento de acidentes por animais peçonhentos. 2.ed. Brasília: Fundação Nacional de Saúde, 2001. 112p.

6 BUCARETCHI F., HERRERA SRF., HYSLOP S., BARACAT ECE., VIEIRA RJ. Snakebites by Crotalus durissus ssp. in children in Campinas, São Paulo, Brazil. Rev. Inst. Med. Trop. São Paulo, 2002, 44, 133-8.

7 BUCARETCHI F., HYSLOP S., VIEIRA RJ., TOLEDO AS., MADUREIRA PR., DE CAPITANI EM. Bites by coral snakes (Micrurus spp.) in Campinas, State of São Paulo, Southeastern Brazil. Rev. Inst. Med. Trop. São Paulo, 2006, 48, 141-5.

8 FRANCO LF. Origem e diversidade das serpentes. In: CARDOSO JLC., FRANÇA FOS., WEN FH., MALAQUE CM., HADDAD JUNIOR V. Eds. ANIMAIS PEÇONHENTOS NO BRASIL: BIOLOGIA, CLÍNICA E TERAPÊUTICA DOS ACIDENTES. São Paulo: Sarvier, 2003, p.13-32. 
9 FRANCO RL., ROCHA CC., JORGE MT., RIBEIRO LA. Snakebites in Southern Minas Gerais State, Brazil. J. Venom. Anim. Toxins, 2001, 7, 56-68.

10 GOIÁS. Secretaria de Estado da Saúde. Regionais de Saúde. [serial online], 2005, [cited 2006 May 20]. Avaiable from: http://www.saude.go.gov.br/index.php?idMateria=2481.

11 GOIÁS. Superintendência de Estatística, Pesquisa e Informação (SEPIN). Anuário estatístico do Estado de Goiás. 1. Situação física. [serial online], 2005, [cited 2006 May 18]. Avaiable from: http://portalsepin.seplan.go.gov.br/pub/anuario/2005/situacao_fisica/area/tab01_area .htm.

12 MARQUES AVO., SAZIMA I. História natural das serpentes. In: CARDOSO JLC., FRANÇA FOS., WEN FH., MALAQUE CM., HADDAD JUNIOR V. Eds. ANIMAIS PEÇONHENTOS NO BRASIL: BIOLOGIA, CLÍNICA E TERAPÊUTICA DOS ACIDENTES. São Paulo: Sarvier, 2003, p.13-32.

13 MARTINEZ EG., VILANOVA MCT., JORGE MT., RIBEIRO LA. Aspectos epidemiológicos do acidente ofídico no Vale do Ribeira, São Paulo, 1985 a 1989. Cad. Saúde Pública, 1995, 11, 511-5.

14 MELGAREJO AR. Serpentes peçonhentas do Brasil. In: CARDOSO JLC., FRANÇA FOS., WEN FH., MALAQUE CM., HADDAD JUNIOR V. Eds. ANIMAIS PEÇONHENTOS NO BRASIL: BIOLOGIA, CLÍNICA E TERAPÊUTICA DOS ACIDENTES. São Paulo: Sarvier, 2003, 33-61.

15 MORENO E., QUEIROZ-ANDRADE M., LIRA-DA-SILVA RM., TAVARES-NETO J. Características clínicoepidemiológicas dos acidentes ofídicos em Rio Branco, Acre. Rev. Soc. Bras. Med. Trop., 2005, 38, 15-21.

16 NOGUEIRA C., SAWAYA RJ., MARTINS M. Ecology of the Pitviper, Bothrops moojeni, in the Brazilian Cerrado. J. Herpetol., 2003, 37, 653-9.

17 PACHECO UP., LEITE CAO., ZORTÉA M. Levantamento das espécies de serpentes da região de Jataí, Estado de Goiás. In: CONGRESSO DE ENSINO, PESQUISA E EXTENSÃO DA UFG, 3, Goiânia, 2006. Anais... Goiânia: UFG, 2006.

18 PAULA-NETO JB., RIBEIRO RSP., LUZ JA., GALVÃO M., CARVALHO SMD., HADDAD JUNIOR V. Clinical and epidemiological characteristics of injuries caused by venomous snakes observed at the Hospital for Tropical Diseases of Araguaína, Tocantins State, Brazil, from 1995 to 2000. J. Venom. Anim. Toxins incl. Trop. Dis., 2004, 11, 422-32. 
19 PINHO FMO., OLIVEIRA ES., FALEIROS F. Acidente ofídico no Estado de Goiás. Rev. Assoc. Med. Bras., 2004, 50, 93-6.

20 PINHO FMO., PEREIRA ID. Ofidismo. Rev. Assoc. Med. Bras., 2001, 47, 24-9.

21 RIBEIRO LA., ALBUQUERQUE MJ., PIRES-DE-CAMPO VAF., KATZ G., TAKAOKA NY., LEBRÃO ML., JORGE MT. Óbitos por serpentes peçonhentas no Estado de São Paulo: avaliação de 43 casos, 1988/93. Rev. Assoc. Med. Bras., 1998, 44, 312-8.

22 RIBEIRO LA., JORGE MT. Acidente por serpentes do gênero Bothrops: série de 3139 casos. Rev. Soc. Bras. Med. Trop., 1997, 30, 475-80.

23 RIBEIRO LA., JORGE MT. Epidemiologia e quadro clínico dos acidentes por serpentes Bothrops jararaca adultas e filhotes. Rev. Inst. Med. Trop. São Paulo, 1990, 32, 436-42.

24 RIBEIRO LA., PUORTO G., JORGE MT. Bites by the Colubrid snake Philodryas olfersii: a clinical and epidemiological study of 43 cases. Toxicon, 1999, 37, 943-8.

25 SALOMÃO MG., ALBOLEA ABP., GONÇALVES ES., ALMEIDA-SANTOS SM. Animais peçonhentos no município de Guarulhos, São Paulo, Brasil: incidência de acidentes e circunstâncias com vista a sua prevenção. Pub. Avulsas Inst. Pau Brasil, 2005, 9, 77-83.

26 SGARBI LPS., ILIAS M., MACHADO T., ALVAREZ L., BARRAVIERA B. Human envenomations due to snakebites in Marilia, State of São Paulo, Brazil: a retrospective epidemiological study. J. Venom. Anim. Toxins, 1995, 1, 70-8.

27 SILVA CJ., JORGE MT., RIBEIRO LA. Epidemiology of snakebite in a central region of Brazil. Toxicon, 2002, 41, 251-5.

28 TINOCO HB., NORBERG AN., PILE E., CARVALHO CRP., SILVA DA., GUERRA-SANCHES F. Snake envenomations in northwest counties of the Rio de Janeiro State, Brazil. J. Venom. Anim. Toxins incl. Trop. Dis., 2005, 11, 34-8. 